\title{
Stare nowe zapożyczenia w rosyjskiej terminologii ekonomicznej
}

Słowa klucze: język rosyjski, leksyka, zapożyczenia, zmiany semantyczne

Język rosyjski ostatnich lat XX i początku XXI wieku jest przedmiotem zainteresowania wielu badaczy (Костомаров 1994, Ферм 1994, Дуличенко 1995, Širjaev (red.) 1997, Шапошников 1998, Земская (отв. ред.) 2000, Валгина 2001, Крысин (ред.) 2008). W ich pracach rozpatrywane są zmiany językowe na poziomie leksyki, słowotwórstwa, morfologii i składni, wywołane przemianami, jakie zaszły w tym czasie w różnych sferach życia w Rosji ${ }^{1}$. Wszyscy zgodnie potwierdzają, że zmiana państwowości, odejście od dawnych społecznych, ekonomicznych, politycznych i duchowych podstaw życia społecznego znalazły najszersze odzwierciedlenie w słownictwie współczesnego języka rosyjskiego. Jak zauważa T. Smółkowa, „leksykę jako całość cechuje otwartość, a na przestrzeni ostatniego półwiecza duży stopień jej dynamiczności zależy przede wszystkim od czynników pozajęzykowych. Słowa wędrują, zmieniają swoje pierwotne miejsce, funkcjonują jednocześnie w kilku polach tematycznych, w różnych odmianach. Z tego względu obserwowana we wszystkich warstwach, z wyjątkiem leksyki podstawowej,

1 Podobne zjawiska, wywołane przemianami ustrojowymi, można obserwować w większości krajów byłego bloku sowieckiego. Zostały one przedstawione m.in. w serii Najnowsze Dzieje Języków Słowiańskich, wydanej przez Uniwersytet Opolski. 
zmienność leksyki w okresie powojennym jest jej najbardziej charakterystyczną cechą" (Smółkowa 2001: 119).

Podstawowe zmiany w sferze leksyki języka rosyjskiego sprowadzają się do następujących procesów:

1) dezaktualizacja jednych zasobów leksykalnych i aktualizacja innych,

2) deideologizacja leksyki,

3) przewartościowanie określonych grup leksyki,

4) rozszerzenie lub zwężenie znaczenia jednostek leksykalnych,

5) intensywne wzajemne oddziaływanie języka literackiego, potocznego $\mathrm{i}$ innych warstw słownictwa języka rosyjskiego.

Należy tu jednak mówić tylko o pewnych procesach zachodzących w leksyce języka rosyjskiego na przestrzeni ostatnich niespełna dwudziestu lat, a nie o ustalonych rezultatach przekształceń językowych. Zmiany znaczeniowe leksemów są procesami diachronicznymi, zachodzącymi w planie historycznej ewolucji zasobu leksykalnego. Przemiany, jakie obserwuje się obecnie we współczesnym języku rosyjskim, są tak samo burzliwie, jak i przemiany polityczne, i nie wiadomo, które ze zmian językowych staną się normą, a które okażą się krótkotrwałe i odejdą w niepamięć (Ермакова 2000: 33).

Większość tych procesów można zaobserwować w leksyce związanej ze sferą ekonomii. Istnieje nawet pogląd, że jest to warstwa słownictwa, w której obserwuje się największą aktywność w dziedzinie jej wzbogacania i zmian semantycznych (Шапошников 1998: 106).

Terminologia ekonomiczna, niezależnie od języka, w którym funkcjonuje, stanowi bardzo zróżnicowaną grupę leksykalną. W jej skład wchodzą wyrazy i związki wyrazowe należące do języka ogólnoliterackiego, terminy z tych wszystkich dziedzin gospodarki, które uczestniczą w obrocie handlowym, a także terminy ściśle ekonomiczne, dotyczące transakcji handlowych, obsługujące dokumentację i korespondencję handlową (Mąkosza 1980: 16). Znajdziemy tu także terminy prawnicze, finansowe, słownictwo związane $\mathrm{z}$ ubezpieczeniem, transportem, służbą celną $\mathrm{i}$ inne.

Na rosyjską terminologię ekonomiczną składa się leksyka rodzima i zapożyczona z innych języków. Według badań J. Mąkoszy (1980: 110) najwięcej pożyczek (około 90\% terminów) zawiera terminologia handlu zagranicznego, niemniej jednak słownictwo obsługujące inne działy gospodarki także jest w dużym stopniu nasycone elementami obcojęzycznymi. Niewątpliwie 
jest to spowodowane tym, że leksyka ta ze swej natury jest leksyką międzynarodową.

Na kształtowanie się rosyjskiej terminologii ekonomicznej, poczynając od XIV stulecia do końca XIX wieku, oddziaływały języki łaciński, grecki, niemiecki, francuski, włoski i hiszpański. Obecnie największy wpływ na współczesną rosyjską terminologię ekonomiczną ma język angielski, który od początku XX stulecia jest prawie jedynym źródłem zapożyczeń dla tej grupy słownictwa.

\section{Dezaktualizacja jednych zasobów leksykalnych i aktualizacja innych}

Współczesna rosyjska terminologia ekonomiczna nie powstała w pustce. Jeszcze do niedawna w powszechnym użyciu była leksyka socjalistycznej gospodarki planowej okresu radzieckiego, która po 1991 r. zdezaktualizowała się i odeszła do słownictwa biernego, powiększając zasób archaizmów, por. план, перевыполнить, соисоревнование, передовик, пятилетка, норма прибыли, овеществленный труд, колхоз, совхоз, субботник, великие стройки коммунизма.

Odchodzące w przeszłość słownictwo i połączenia wyrazowe ustąpiły miejsca nominacjom odzwierciedlającym nowe realia gospodarcze i ustrojowe. Otwarcie rosyjskiej gospodarki na Zachód i włączenie jej przedstawicieli do międzynarodowego grona handlowców i bankowców zaowocowało licznymi zapożyczeniami terminów ekonomicznych, przede wszystkim z języka angielskiego i jego wariantu amerykańskiego: бартер, аудит, ваучер, клиринг, лизинг, маректинг, консалтинг, холдинг, франчайзинг, дилер, менеджер i inne. Przekroczyły one granice swego naturalnego środowiska językowego, pojawiły się w różnych tekstach, w których stały się narzędziem opisu złożonych zjawisk i relacji, dających się zaobserwować w rzeczywistości pozajęzykowej. Taką sytuację opisuje M. W. Kitajgorodskaja: „Магическое слово «рынок», прозвучавшее на первых съездах народных депутатов, символизировало этот поворот в экономическом развитии. За ним последовала целая лавина новых «экономических» слов хронологических маркеров происходящих перемен. Экономическая терминология смела границы традиционного узкопрофессионального употребления. Она щедро выплеснулась на книжные лотки в виде 
многочисленных актуальных изданий по менеджменту и маркетингу, лизингу и консалтингу, бухучету и аудиту и мн. др., зазвучала в устной речи на радио и телевидении. В условиях инфляции «курс доллара» стал не менее актуальной информацией, чем сводка погоды” (Китайгородская 2000: 163).

Wiele wyrazów odnoszących się do tej sfery, takich jak рынок, приватизация, ваучер, инфляциия, stało się kluczowymi na początku lat 90. ze względu na to, że oznaczane przez nie pojęcia znalazły się w centrum zainteresowania społecznego (Земская 2000: 92, 94). Wyrazy te charakteryzują się dużą częstotliwością użycia w języku mediów i w języku mówionym różnych warstw społeczeństwa. Zdaniem E. A. Ziemskiej (Земская 2000: 92), aktywność słów kluczy wpływa nie tylko na ich potencjał słowotwórczy, ale i na związki z innymi wyrazami, kiedy to aktualizują się te czy inne relacje między wyrazami systemu leksykalnego języka.

Nowe zjawiska w teraźniejszej rzeczywistości ekonomicznej opisują także terminy zapożyczone wcześniej z różnych języków: z języka niemieckiego, por.: банк (XVII w.), вексель (XVII w.), биржа (XVIII w.), спекуляциия (XVIII w.), кризис (XVIII w.), маклер (XVIII w.), банкир (XVIII w.), акционер (XVIII w.), банкрот (XVIII w.), котировка (XIX w.), фирма (XIX w.); z języka francuskiego: акц̧из (XVIII w.), антерпренер (XVIII w.), кредит (XVIII w.), бюджет (XIX w.); z języka włoskiego, por.: меценат (XVIII w.), импресарио (XIX w.); z języka angielskiego, por.: инфляция (1 poł. XX w.) i inne. Funkcjonowały one jako neutralne wyrazy w języku przedrewolucyjnej Rosji, lecz na skutek zerwania ciągłości pokoleniowej są teraz odbierane jako zupełnie nowe terminy. W literaturze przedmiotu (Китайгородская 2000: 173; Валгина 2001: 78; Надель-Червиньска 2006: 73) tego typu wyrazy określane są jako słownictwo powracające do aktywnego użycia (возвращаемые слова lub возвращенные слова).

Równolegle do tego zjawiska w ramach terminologii ekonomicznej zaobserwowano także tak charakterystyczne dla współczesnej rzeczywistości językowej zastępowanie funkcjonujących wcześniej obcojęzycznych terminów nowymi wariantami angielskimi, por.: брокераж (franc.) 'проведение сделок по ценным бумагам' - брокеридж (ang.) (MES: 70); куртаж (franc.) 'вознаграждение, получаемое брокером' - брокеридж (ang.) (MES: 367). 


\section{Deideologizacja leksyki}

Większość współczesnych terminów ekonomicznych była rejestrowana przez słowniki okresu radzieckiego ${ }^{2}$, zawsze jednak były one opatrzone informacją, że oznaczają realia związane ze światem kapitalistycznym, co automatycznie wiązało się $\mathrm{z}$ negatywną oceną tego zjawiska. W ten sposób podkreślano opozycję: swój - nie nasz, ideologicznie obcy, dobry - zły, por.:

- банк '1. а) в социалистических странах (podkreślenia moje - W. M.): государственное учреждение, осуществляющее в соответствии с народнохозяйственным планом кредитование текущей деятельности предприятий и финансирование капиталовложений, организующее безналичные денежные расчеты между предприятиями и хозяйственными органами и централизованный кругооборот наличных денег; б) в капиталистических странах: предприятие, концентрирующее ссудный капитал и предоставляющее его в распоряжение капиталистов для получения прибыли и сверхприбыли' (MAS, I: 60);

- банкир 'крупный акционер или владелец банка в капиталистических странах’ (MAS, I: 60);

- бизнесмен 'в капиталистическом мире: делец, предприниматель' (OŻG-81: 46);

- кризис '2. экон. периодическое относительное перепроизводство товаров в капиталистическом обществе, ведущее к расстройству экономической жизни, к безработице и нищете трудящихся’ (MAS, II: 129 );

- маклер 'профессиональный посредник при заключении торговых и биржевых сделок в капиталистческих странах и в дореволюционной России' (MAS, II: 217);

- спекуляиия 1. 'скупка товаров и перепродажа их по повышенным ценам с целью наживы'; 2. 'в капиталистических странах: биржевая игра на повышение или понижение курса ценных бумаг’ (MAS, IV: 220);

2 Словарь русского языка в четырех томах под ред. А. П. Евгеньевой, nazywany małym słownikiem akademickim (MAS) wydawany w latach 1957-1961, drugie wydanie tego słownika ukazało się w latach 1981-1984; Толковый словарь русского языка С. И. Ожегова - pierwsze wydanie ukazało się w 1949 roku, później był wielokrotnie wznawiany, od 1992 roku jego współautorem jest Н. Ю. Шведова. 
- биржа 'в буржуазных странах: учреждение для заключения финансовых и коммерческих сделок’ (OŻG-81: 46).

Wraz ze zmianą ustroju gospodarczego wszystkie te wyrazy stały się nazwami pojęć występujących także w realnej rzeczywistości Rosji, poszerzyły korelację referencjalną i w rezultacie można było nazwać je „naszymi”, „swoimi” wyrazami (Китайгородская 2000: 172). Według O. P. Jermakowej, „процесс деидеологизации лексики проявляется в освобождении значений некоторых слов от идеологических смысловых приращений, в частности, в снятии пейоративной окраски, которая была обусловлена восприятием денотата сквозь призму коммунистической идеологии, или, напротив, в появлении неодобрительной или иронической окраски в связи с идеологическими коннотациями" (Ермакова 2000: 36). W słownikach opisowych, wydanych po 1991 roku, leksemy te zostały pozbawione negatywnego nacechowania ideologicznego i funkcjonuja jako neutralne jednostki leksykalne opisujące współczesne realia. Ich znaczenia są zgodne z definicjami, zawartymi we współczesnych terminologicznych słownikach ekonomicznych (por. np. MES), choć niektóre częściowo zachowują poprzednie nacechowanie negatywne, wyrażone kwalifikatorami разг. і неодобр., nр.:

- бизнесмен 1. 'организатор бизнеса; предприниматель, коммерсант'; 2. разг. 'о мошеннике, жулике' (TSRJ: 86);

- спекуляция 1. неодобр. 'скупка товаров в условиях дефицита и перепродажа их по повышенным ценам с целью получения прибыли'; 2. 'биржевая сделка купли-продажи ценных буамг с целью получения курсовой разницы’ (TSRJ: 603).

W pozostałych przypadkach usunięcie informacji o związkach z innym ustrojem gospodarczym wystarczyło, by uznać omawiane leksemy za neutralne, a tym samym pozbawione negatywnych konotacji, por.:

- банк 'учреждение, осуществляющее финансовые действия с ценными бумагами и деньгами населения, предприятий, фирм; осуществляющее финансирование различных пректов, выдачу кредитов под проценты и т.п.' (TSRJ: 73);

- банкир 'владелец банка, управляющий банком; член правления банка' (TSRJ: 74); 
- кризис 1. 'тяжелое, нестабильное состояние, положение чего-л., гдел.'; 2. 'острый недостаток, нехватка чего-л.' (TSRJ: 341);

- маклер 1. 'тот, кто профессионально занимается посредничеством при купле-продаже, заключении различных сделок и т.п.'; 2. 'служащий биржи, работающий с брокерами и выполняющий поручения членов фондовой биржи за комиссионное вознаграждение' (TSRJ: 370);

- биржа 'организационная форма рынка, характреизующаяся свободной торговлей товарами, ценными бумагами и т.п. и формированием рыночных цен на основе фактического соотношения спроса и предложения; учреждение такого типа' (TSRJ: 93).

Ciekawym przykładem zmian znaczeniowych jest termin спекулянт, por.:

- спекулянт 1. 'тот, кто занимается спекуляцией (в 1 знач.)' Рыночный спекулянт; 2. перен. 'тот, кто строит свои планы, расчеты на чем-л., пытается использовать что-л. в корыстных целях’ (MAS, IV: 220);

- спекулянт 1. неодобр. 'тот, кто занимается спекуляцией (1 зн.)'; 2. 'тот, кто профессионально занимается спекуляцией (2 зн.)' (TSRJ: 603).

W drugim, przenośnym znaczeniu, odnotowanym w MAS, спекулянт oznacza kogoś związanego z filozoficznym pojmowaniem spekulacji, tzn. z dociekaniami abstrakcyjnymi nie liczącymi się z rzeczywistością, oderwanymi od życia i praktyki. Taki opis potwierdza odcięcie się od pojęć związanych z ustrojem kapitalistycznym, choć w haśle słownikowym brak takiej adnotacji. Pierwsze znaczenie tego wyrazu jest neutralne i wynika z ówczesnego rozumienia spekulacji jako 'скупки товаров и перепродажи их по повышенным ценам с целью наживы'. To znaczenie wyrazu спекулянт rejestruje także wydany w 1998 roku TSRJ, jednak opatruje je kwalifikatorem неодобр., wyrażającym negatywną ocenę tego zjawiska. Natomiast jako drugie znaczenie pojawia się już terminologiczne określenie ekonomiczne.

\section{Przewartościowanie określonych grup leksyki}

Część terminologii ekonomicznej, używanej przed rewolucją i po niej, aktualizując się, podlega przewartościowaniu. Terminy odnoszące się do świata kapitalistycznego w czasach radzieckich wywoływały negatywne reakcje emocjonalne, ponieważ oznaczały realia uznane za gorsze. Obecnie wraz 
z rehabilitacją pojęć słownictwo to uwolniło się od negatywnego zabarwienia i stało się neutralne emocjonalnie, a nawet pozytywnie nacechowane. Można to zaobserwować, porównując zapisy leksykograficzne terminów zapożyczonych, jak i ich rodzimych odpowiedników, por.:

- бизнес разг. 'деловое предприятие, ловкая афера и т.п. как источник личного обогащения, наживы' (MAS, I: 89) - бизнес 'предпринимательская деятельность, связанная с коммерцией, призводством и реализацией товаров, оказанием услуг населению и т.п.' (TSRJ: 85);

- бизнесмен 1. 'организатор бизнеса; предприниматель, коммерсант'; 2. разг. 'о мошеннике, жулике' (TSRJ: 86) - бизнесмен 'тот, кто занимается бизнесом; предприниматель, делец’ (BTS: 77);

- делец 'человек, который ловко ведет свои дела, не стесняясь в средствах для достижения своекорыстных целей' (OŻG-81: 46) - делеи 'человек, который успешно (иногда не стесняясь в средствах) ведет дела' (OŻG-96: 154);

- предприниматель 1. 'капиталист-владелец промышленности, торгового и т.п. предприятия.'; 2. неодобр. 'делец, ловкий организатор выгодных предприятий' (MAS, III: 369) - предприниматель 'тот, кто имеет свое дело, владеет предприятием или на свой риск занимается какой-л. экономической деятельностью, приносящей личный доход’ (TSRJ: 497).

Jak widać, w hasłach przytoczonych ze starszych słowników, oprócz kwalifikatorów разг., неодобр. przekazujących negatywną ocenę omawianych zjawisk, zastosowano środki leksykalne - wyrazy i połączenia wyrazowe (ловкая афера, нажива, ловко ведет, свеоекорыстные цели, капиталиствладелеи, выгодное предприятие), podkreślające ich wartość pejoratywną. W słownikach wydanych po 1991 roku wszystkie te wyrazy pozbawione są negatywnie wartościujących określeń i stają się emocjonalnie neutralne, a nawet zabarwione pozytywnie. Mamy tu do czynienia ze swoistą melioracja znaczeniową (Buttler 1978: 158-164).

Istnieje też inny pogląd na ten temat. N. S. Wałgina (Валгина 2001: 78) uważa, że cechą charakterystyczną tego typu wyrazów jest „rozdwojona konotacja” (,расщепленная коннотация”). W związku z ideową i materialną dyferencjacją społeczeństwa te same wyrazy u różnych grup ludzi wywołują różne konotacje wartościujące. Spowodowane jest to odwiecznymi procesa- 
mi istniejącymi w każdym społeczeństwie, a mianowicie rozwarstwieniem społeczeństwa ze względu na stan posiadania. Przez tzw. nowych Rosjan wyrazy бизнес, бизнесмен, предприниматель, делец odbierane są bezwarunkowo pozytywnie, stanowią nieodłączną część ich image’u. Natomiast tym, którzy na skutek przemian ekonomicznych zubożeli lub wręcz stracili wszystko, wyrazy te będą kojarzyć się z oceną zdecydowanie negatywną.

Zmiany społecznego odczucia wartości stylistycznej można zaobserwować także na przykładzie, utworzonych od zapożyczonych terminów, wyrazów биржевик i рыночник, które w BTS, wydanym w 1998 roku, zarejestrowane były jako wyrazy potoczne z kwalifikatorem paзz., ale już w TSRJ XXI z 2007 roku odnotowane zostały jako terminy z dziedziny finansów i ekonomii, por::

- биржевик разг. 'тот, кто занимается биржевыми операциями; биржевой делец' (BTS: 79) - биржевик фин. 'специлист, занимающийся биржевыми операциями' (TSRJ XXI: 134);

- рыночник разг. 'сторонник рыночной экономики' (BTS: 1137) - pblночник экон.' сторонник рынка (1 зн.) как основы хозяйственной жизни страны, рыночной экономики; специалист по рыночной экономике' (TSRJ XXI: 874).

\section{Rozszerzenie lub zawężenie znaczenia jednostek leksykalnych}

Rozszerzenie i zawężenie znaczenia należy do podstawowych typów przekształceń znaczeniowych. Zawężenie znaczenia (inaczej specjalizacja znaczenia) to proces polegający na ograniczeniu treści leksemu. Wyraz, który oznaczał kiedyś pewien zbiór przedmiotów, z biegiem czasu zaczyna być używany tylko w odniesieniu do niektórych przedmiotów ze zbioru (Kania, Tokarski 1984: 172). Procesem odwrotnym do poprzedniego jest rozszerzenie znaczenia. O rozszerzeniu znaczenia wyrazu, czyli generalizacji, mówimy, gdy wyraz zmienia swoje znaczenie, rozszerzając swój zakres stosowalności z jednego tylko rodzaju przedmiotów czy zjawisk na cały szerszy zbiór, do którego dane przedmioty czy zjawiska należą (Kania, Tokarski 1984: 172).

Można to zjawisko prześledzić na przykładzie znanego od dawna w języku rosyjskim wyrazu рынок, zapożyczonego na przełomie XVII i XVIII wieku z języka niemieckiego za pośrednictwem języka polskiego (KESRJ: 397). W realiach radzieckich pojęcie rynku wiązało się głównie z bazarem, na 
którym handlowano różnymi produktami żywnościowymi. Terminologiczne znaczenie tego wyrazu oczywiście było rejestrowane przez słowniki tego okresu, jednak sam on należał do zasobów słownictwa specjalistycznego i nie był powszechnie używany, por.: рынок 1. 'место розничной торговли съестными припасами и другими товарами под открытым небом или в крытых торговых рядах; базар', 2. экон. 'сфера товарного обращения, товарооборота' (MAS, III: 747).

Wraz ze zmianami ustroju znaczenie wyrazu рынок uległo znacznemu rozszerzeniu, oznaczając jeszcze inne zjawiska związane z nowym systemem gospodarczym. We wszystkich słownikach opisowych końca XX wieku (BTS, TSRJ, TSRJ XX) jako pierwsze rejestrowane jest znaczenie terminologiczne. Pojawiają się także nowe ściśle z nim związane znaczenia, wynikające z metonimicznego przeniesienia nazwy (patrz znaczenie 3. i 5.), por.: рынок 1. 'сфера свободного обращения товаров и капиталов, а также движения рабочей силы, регулируемых спросом и предложением; условия и возможности для свободной купли-продажи'; 2. 'область деятельности, творчества, осуществляемых в условиях конкуренции; сфера свободного выбора'; 3. только ед. 'рыночная экономика'; 4. 'место розничной торговли под открытым небом или в павильоне'; 5. 'группа, слой населения, который является покупателем какого-л. товара' (TSRJ: 555).

Rozszerzenie znaczenia znajduje odzwierciedlenie w nowych połączeniach wyrazowych, których dominanta jest wyrazрынок. Oprócz odnotowywanych wcześniej wyrażeń продовольственный рынок, павильоны рынка, słowniki rejestrują zwroty внешний, внутренний рынок, товарный рынок, финансовый рынок, рынок зерна, рынок капиталов, рынок бытового обслуживания, рынок страховых, таможенных, аудиторских услуг, программа перехода к рынку, модель формирования рынка, жить в условиях рын$\kappa а$, читательский рынок i inne, opisujące proces tworzenia gospodarki rynkowej w Rosji.

Specjalizację i uściślenie znaczeń można zaobserwować także, porównując bliskie semantycznie stare i nowe zapożyczenia, por.:

- меценат (wł.) ‘богатый покровитель' - антерпренер (franc.) 1. 'частный театральный предприниматель', 2. 'лицо, добывающее средства для организации, предприятия и этим самым возлагающее на себя предпринимательский риск’ - импресарио (wł.) 'предприниматель, 
устроитель зрелищ' - спонсор (ang.) 'лицо, оказывающее финансовую поддержку' - продюсер (ang.) 'доверенное лицо кинокампании' - промоутер (ang.) 'тот, кто способствует продвижению на рынке, покровитель, патрон'.

- бухгалтер (niem.) 'специалист по теории и практике счетоводства и учета' - ревизор (łac.) 'лицо, уполномоченное произвести ревизию, обследование деятельности какого-либо учреждения или должностного лица' - aydumop (ang.) 'лицо, которое проверяет состояние финансово-хозяйственной деяельности организаций и предприятий'.

Przytoczonych wyżej starych i nowych zapożyczeń nie można traktować jako dubletów. Relacje semantyczne między nimi są bardziej złożone, każdy $\mathrm{z}$ tych terminów posiada w swym znaczeniu elementy odróżniające je od innych wyrazów w ciągu.

Na podstawie przeanalizowanych przykładów można stwierdzić, że chociaż wiele terminów ekonomicznych będących starymi pożyczkami z innych języków powróciło do aktywnego użycia we współczesnym języku rosyjskim, to jednak zostały one bądź poddane różnorodnym zmianom semantycznym, bądź zastąpione nowymi zapożyczeniami z języka angielskiego.

\section{Objaśnienia skrótów}

BTS - Кузнецов С. А., 1998, Большой толковый словарь русского языка, СанктПетербург: Норинт.

KESRJ - Шанский Н. М., Иванов В. В., Шанская Т. В., 1975, Краткий этимологический словарь, Москва: Просвещение.

MAS - Евгеньева А. П. (red.), 1981-1984, Словарь русского языка в четырех mомах, Москва: Издательство Русский язык.

MES - Азрилиян А. Н. (red.), 2000, Мальий экономический словарь, Москва: Институт новой экономики.

OŻG-81 - Ожегов С. И., 1981, Толковый словарь русского языка, Москва: АЗЪ.

OŻG-96 - Ожегов С. И., Шведова Н. Ю., 1996, Толковый словарь русского языка, Москва: АЗЪ.

TSRJ - Скляревская Г. Н. (red.), 1998, Толковый словарь русского языка XX в. Языковые изменения, Санкт-Петербург: АСТ.

TSRJ XX - Скляревская Г. Н. (ред.), 2001, Толковый словарь современного русского языка. Языковые изменения кониа ХХ столетия, Москва: Эксмо. 
TSRJ XXI - Скляревская Г. Н. (ред.), 2007, Толковый словарь русского языка начала XXI века. Актуальная лексика, Москва: Эксмо.

\section{Bibliografia}

ButtLeR D., 1978, Rozwój semantyczny wyrazów polskich, Warszawa: Wydawnictwa Uniwersytetu Warszawskiego.

Дуличенко А. Д., 1995, Русский язык конца XX столетия: некоторые тенденции развития, Przeglad Rusycystyczny, z. 3-4 (71-72), s. 189-204.

Ермакова О. П., 2000, Семантические процессы в лексике, w: Е. А. Земская (red.), Русский язык конщу ХХ столетия (1985-1995), Москва: Языки славянских культур, s. 32-66.

Ферм Л., 1994, Особенности развития русской лексики в новейший период (на материале газет), Uppsala: Uppsala University.

Kania S., ToKarski J., 1984, Zarys leksykologii i leksykografii polskiej, Warszawa: Wydawnictwa Szkolne i Pedagogiczne.

КИТАЙГородСКАЯ М. В., 2000, Современная экономическая терминология. (Состав. Устройство. Функционирование.), w: Е. А. Земская (red.), Русский язык кониа ХХ столетия (1985-1995), Москва: Языки славянских культур, s. $162-236$.

Костомаров В. Г., 1994, Языковой вкус эпохи. Из наблюдений над речевой практикой масс-медиа, Москва: Педагогика-Пресс.

Крысин Л. П. (red.), 2008, Современный русский язык: Активные процессы на рубеже XX-XXI веков, Москва: Языки славянских культур.

Mąкosza J., 1980, Сопоставительный анализ терминологии внешней торговли в русском и польском языках (иноязычные элементы), Warszawa: SGPiS.

НАДЕль-ЧЕрвиньскА М., 2006, Новая лексика в русских толковых словарях конияа XX - начала XXI веков, Katowice: Wydawnictwo Uniwersytetu Śląskiego.

ШАпошников В., 1998, Русская речь 1990-ыхх годов. Современная Россия в языковом отображении, Москва: МАЛП.

SмóŁкоwa T., 2001, Leksyka ogólna - neologizmy, w: S. Gajda (red.), Najnowsze dzieje języków stowiańskich. Język polski, Opole: Uniwersytet Opolski - Instytut Filologii Polskiej, s. 119-206.

ŠIRJAEv E. (red.), 1997, Najnowsze dzieje języków stowiańskich. Русский язык, Opole: Uniwersytet Opolski - Instytut Filologii Polskiej.

Валгина Н. С., 2001, Активные проиессы в современном русском языке, Москва: Логос.

Земская Е. А. (отв. ред.), 2000, Русский язык конца ХХ столетия (1985-1995), Москва: Языки славянских культур. 
ЗЕмская Е. А., 2000, Активные процессы современного словопроизводства, w: Е. А. Земская (red.), Русский язык кониа ХХ столетия (1985-1995), Москва: Языки славянских культур, s. 90-141.

\section{Старые новые заимствования \\ в русской экономической терминологии}

\section{(резюме)}

В статье рассматриваются термины, называющие новые явления современной русской экономической действительности, которые были заимствованы из других языков в прошлом (XVII - нач. XX в.) и в досоветский период функционировали в русском языке как нейтральные, фиксируя реалии того времени. Такие «возвращенные» термины (бизнес, биржа, кризис, акцииз и др.) часто воспринимаются как совсем новые слова. В связи с изменениями в общественно-политической жизни России они подвергаются разным семантическим изменениям: деидеологизации, актуализации, переоценке, расширению или сужению значений. 